Article

\title{
Biographical Profiling of Nikola Tesla for the Creation of an Engaging Story
}

\author{
Yannis Hadzigeorgiou (D)
}

check for updates

Citation: Hadzigeorgiou, Y. Biographical Profiling of Nikola Tesla for the Creation of an Engaging Story. Educ. Sci. 2022, 12, 12. https:// doi.org/10.3390/educsci12010012

Academic Editors: Ian Hay and Eleanor Dommett

Received: 10 September 2021 Accepted: 20 December 2021 Published: 28 December 2021

Publisher's Note: MDPI stays neutral with regard to jurisdictional claims in published maps and institutional affiliations.

Copyright: (C) 2021 by the author. Licensee MDPI, Basel, Switzerland. This article is an open access article distributed under the terms and conditions of the Creative Commons Attribution (CC BY) license (https:// creativecommons.org/licenses/by/ $4.0 /)$.
School of Humanities, University of the Aegean, 81100 Mitilini, Greece; hadzigeo@aegean.gr

\begin{abstract}
This paper focuses on the potential of storytelling as a means of influencing students to become engaged with science and to choose a career in a STEM field. Given the role that leaders can play in motivating and influencing people and considering Nikola Tesla a leader in the fields of electrical engineering and science, the paper identifies Tesla's leadership traits, as these emerge from his life story, that is, actual historical events regarding his life and his scientific/technological work. These leadership traits refer to (a) imaginative thinking and innovation, (b) persistence/perseverance, and (c) vision, and point to the need for empirical studies to document the effectiveness of the Nikola Tesla story to motivate and influence students. The significance of the Nikola Tesla story for science education is also discussed.
\end{abstract}

Keywords: storytelling; science; Nikola Tesla; leadership traits; engagement; influence

\section{Introduction}

It is a fact that narrative and storytelling have been used to communicate ideas about science [1-7]. Ever since Bruner made the distinction between two modes of thinking, namely, the paradigmatic (or logico-mathematical) and the narrative [8], the role of the latter in communicating information about science has received attention by both researchers and educators [9]. The narrative mode has been associated with the terms "narrative" and "story", which, more often than not, are used interchangeably. However, it is crucial to distinguish between the two: "a narrative can be considered a flow of events associated with a theme/idea, while a story can be considered a sequence of these events to create meaning" [9]. Most likely, narratives represent the most natural and earliest ways in which we organize our experience and our knowledge, and that is why Bruner believed that the narrative mode of thinking represents a "default" mode of thinking [10]. In regard to storytelling per se, it has been pointed out that, "a story with just a few well-chosen words, can engage the listener and create a world of shared experience, something that a technical analysis might not easily do" [11].

However, while the importance of communicating science content knowledge and knowledge of the nature of science has been recognized [1,12], it is crucial that such knowledge is tied to a human context for a number of reasons. First and foremost, students become aware that knowledge of and about science is always tied to certain individuals who created such knowledge, that is, to their hopes, dreams and ambitions, struggles, successes and failures. In other words, knowledge is not something abstract and inert but something 'alive' that emerges out of a human context [13-15]. Second, humanizing knowledge can motivate and even inspire students to become engaged with a STEM field [13,16-19]. Third, but equally important, students become aware of the fact that the world, as we know it today, is the result of the application of innovative ideas and the vision of certain individuals — not so many if one attempted to count them-who can be considered leaders in their field, as they literally transformed the world we live in. It is indeed the human context that can communicate to an audience the personal traits of scientists, mathematicians and engineers, and their vision as leaders in their respective fields. 
Even though a leader, according to the literature on leadership [20-23], is one who leads people (i.e., one who establishes a vision, fosters collaboration and motivates and inspires others to realize that vision), individuals who work in STEM fields are leaders in the sense that they lead people but also their field, as a result of their innovative ideas and their vision, and also because they can inspire other individuals and teams to work and develop those ideas further.

One such individual, a scientist and an engineer, who has demonstrated individual leadership, even though he had been marginalized by the academic community of his time is Nikola Tesla [24-27]. Most people today associate the name Tesla with the famous electric car, while all physicists and engineers know that the same name has been given to the unit of the magnetic flux density. Yet, Nikola Tesla can be considered a leader in the fields of electrical engineering and science, especially physics, according to the literature on leadership, which points out the characteristics of effective leaders. Such characteristics include self- confidence and determination (i.e., perseverance despite the obstacles in order to achieve a goal), personal integrity (i.e., adherence to personal values), intelligence, innovative thinking, inspiration and vision [21,22,28-31].

The purpose of this paper is to identify Nikola Tesla's leadership traits, by drawing on a variety of sources that report on his life and his scientific/technological work [24-27,32-37]. These traits become crucially important in the context of school science education, and more specifically when an engaging story is to be created for teaching science. First, though, this paper will discuss the reason(s) why storytelling is important as a means of influencing students and the importance of creating an engaging story.

\section{Engaging Storytelling as a Means of Influencing Students}

If stories are effective tools to communicate ideas because of the emotional impact of such ideas on an audience (i.e., the presented information stirs up emotions) $[13,38]$, then stories can be seen as tools for influencing people as well. Telling a story, especially a compelling one, can be an effective way to build trust and to inspire [39], something that has been recognized in leadership studies $[40,41]$. In the context of education, a story that presents to students the leadership traits of a person working in a STEM field, can be inspiring and thus attract and engage students in the study of science [16,42].

While the Science for All initiative $[43,44]$ has been important to get all students to learn about science, attracting the next generation of scientists and engineers is also of crucial importance. There is evidence that physics is not a popular subject. Students appear to prefer biology and environmental education [45], while they are generally reluctant to study physical science beyond compulsory schooling [46]. This empirical evidence concurs with a finding from the ROSE (Relevance of Science Education) project in England [47], namely, that while students do acknowledge the importance of science, they do not really want to study it. It is interesting to note that in an earlier study, students had said that science is indeed important "but not for me" [48]. Apparently, such findings are not encouraging, if one of the goals of school science education is to attract the next generation of scientists and engineers. Therefore, the study of physical science, particularly physics, should be encouraged during the years of compulsory education. The question, then, is how to do this?

One popular answer is by making physics relevant to the lives of students and also by making physics interesting. Who could be against such an idea? It would be really hard to argue against a relevant and interesting physics curriculum. What is a relevant and/or interesting physics curriculum? This question is not easy to answer. Putting aside the conceptual problems inherent in the notions of both relevancy and interest $[18,42]$, there is the practical problem of content selection, and therefore, a question about what kind of physics education students receive. There are, one might argue, moral objections to a curriculum based on the notions of relevance and interest on the grounds that such a curriculum is too narrow in scope and therefore unsuitable for those who must prepare for a university degree in STEM (Science, Technology, Engineering and Mathematics) fields [12]. 
On the other hand, there is a problem of attracting female students to science and engineering. There is evidence, for example, according to a study in the US, that women still lag behind in math-based science fields, such as engineering, geophysics, physical science, and are less likely, in comparison with men, to pursue careers in STEM fields [49]. There is also evidence, according to another study, that women do not choose to study STEM fields, despite their high mathematical abilities [50]. However, if these gender differences in attitudes toward science, and math-based science fields in particular, are not due to lack of ability on the part of women, then attention should be paid to the way in which STEM fields are presented to the students. It is here that narratives and storytelling can be used to humanize the teaching of science and also influence students. While Marie Curie's life events in Paris and her scientific work may inspire female students, Einstein's or Newton's life events and work may inspire male students, even though there is some evidence that Tesla's experiments as presented in the film The Prestige have the potential to inspire female students to pursue a career in electrical engineering [16]. Certainly, longitudinal studies on the role of stories in influencing students to choose a career in a STEM field are long overdue, but the possibility of this idea needs to be seriously considered, especially when stories communicate personality traits of effective leadership.

Certainly, creating a truly engaging story can be a real challenge. For it is true that an engaging and powerful story is a work of art [51]. Just a narrative account of events and experiences, as a result of the action of some characters, does not make an engaging story. A story, as a technique for organizing events, facts characters and ideas into a meaningful unit (i.e., with a beginning that sets up a conflict or expectation, a middle part that makes up the plot, and an end that resolves the initial conflict) [52] does not necessarily engage students with its plot either. Simplicity and irony are also elements to be considered if an engaging and powerful story is to be created [53], as are other elements, such as humor, binary opposites, mental images, mystery, wonder, extremes of reality and experience, heroism, and revolt against convention, that educational theorist Kieran Egan calls "cognitive tools". According to Egan, an engaging story should include in its plot "cognitive tools" appropriate to the age of the listener [53]. However, if a story is to be truly engaging and serve as a means of influencing students in some way, then the personal traits/human qualities of its character(s) deserve particular attention.

For it is true that young students, in their attempt to gain confidence in dealing with the real world, need to associate people with certain human qualities, in order to gain confidence that they, too, can face and deal with the real world. Such qualities may be exemplified in ingenuity, inventiveness, imaginativeness, perseverance and tenacity. Kieran Egan has convincingly argued that when children move from orality to literacy, meaning there is a transition from a magical to a more realistic world, they face many challenges and, as teenagers, they also feel threatened by that world, preoccupied at the same time with such issues as getting along with friends and peers, with success in their personal life and in school, being likable by the opposite sex [53]. The point to be made here is that young people tend to associate with those qualities that they themselves think they need, in order to successfully cope with the real world. In other words, they themselves choose the human qualities they will associate and identify with. Tesla's leadership traits do represent human qualities that young students can identify with. It is true that young people choose their heroes or heroines and that these, more often than not, are soccer players and pop stars. However, they can also be other professionals, such as artists and scientists. These heroes or heroines are freely chosen because they embody human qualities and values, which, from the moment they are chosen, become 'heroic'. Tesla's human qualities may very well be considered 'heroic' (i.e., transcendental), just like, for example, Marie Curie's courage and perseverance to pursue her scientific work despite the challenges and hardships of her daily life in Paris. From such a perspective, a story that is to be used for teaching alternating current electricity should include not just Tesla's life events but his personality traits as well, if that story is to be engaging and inspiring. 


\section{Biographical Profiling of Tesla's Leadership Traits}

Drawing on a variety of sources [24-27,32-37] and using narrative biography, as a form or genre of narrative research [54-56], this paper identifies Nikola Tesla's leadership traits, as these emerge from a number of life events. These events can be embedded in the plot of a story, for the purpose of motivating and inspiring students not only to become engaged with the study of science, but also to choose a career in a STEM field. Given that narrative biography can portray the life events of a person without the need for a comprehensive account of life events, from birth to death or for an absolute facticity, its goal is not an ultimate interpretation of those life events [56]. Thus, a reading and interpretation of Tesla's life events gave the following three leadership traits: imaginativeness, persistence/perseverance and vision. Certainly, the personal bias in this process is to be acknowledged (e.g., personal emotions toward the subject of the research), as is always the case with narrative biography $[54,56]$, especially in this case, where the material to be interpreted is text written by others and not text transcribed from original interviews with the subject (i.e., Tesla).

\subsection{Tesla's Imagination}

One crucial characteristic of good leaders, according to the literature on leadership, is that they are innovative. However, it is creative imagination that makes someone a creative and innovative leader [35]. In fact, one could even argue for an "imaginative" type of leadership and the need for such a type [57], in the sense that, while imagination may be seen as a latent trait of most, if not all, types of leadership (e.g., strategic, transactional, democratic, strategic, transformational, innovative, invisible, emotional), imagination is a central characteristic of "imaginative leadership", which is also about human progress [58]. Tesla's life-events provide ample evidence for imaginative thinking in the form of both possibility thinking and visualization. Tesla could indeed visualize both complex ideas and apparatuses and he could think in terms of the possible rather than the actual. It is these abilities of Nikola Tesla that made a contribution to human progress [24].

With regard to Tesla's ability to think in terms of the possible, the first thing that should be noted is that the realization of the idea of alternating current (AC) electricity became possible because of such an ability. It was he, while studying at the Graz Polytechnic Institute, in Austria, that perceived the possibility, not only of the idea of AC electricity, but also of putting it to use. This is important to point out, given that at the time there was only some theoretical talk about AC, but no one could think about how to use it in practice and making it useful in everyday life. The second thing to be noted concerns the idea of the wireless transmission of electrical power. It was an unconceivable idea at the time, but Tesla could see the possibility of developing it and thus putting it to the service of humanity.

With regards to Tesla's extraordinary ability to visualize, there are many examples that illustrate such an ability. First of all, both an understanding of the idea of alternating current (AC) and its application were made possible due to Tesla's such ability. He could visualize its 'wavy' character and 'play' with the various images in his mind. This visualization made him also conceive of the idea of transformation, which was central to his further work on AC electricity. Second, the idea of the electric motor was visualized by Tesla while on a walk at a park, even though it appears that such an idea came to him as a vision. Third, during his employment at the Continental Edison Company Tesla solved one of the most difficult problems at the time, namely, the lighting system and powerhouse of the Strasbourg railway station. Tesla, without making a single engineering drawing, managed to build there his first AC motor and dynamo. This work was the foundation for the production of AC electricity. However, his extraordinary ability to visualize can be also seen when his New York laboratory was completely destroyed by a mysterious fire immediately after his success at Niagara Falls, which, in fact, demonstrated the superiority of alternating current compared to the prevailing kind at the time, namely, direct current (e.g., by harnessing the 
power of Niagara Falls, Tesla was successful at transmitting electrical energy to a distance of $25 \mathrm{~km}$, a feat unheard of at the time).

Tesla's imaginative thinking coupled with his ingenuity can be seen in the many applications we use today, like the radio, electric motors and transformers. Even the idea of remote-control motion is due to Tesla's creative imagination. Perhaps the idea of the wireless transmission of electrical energy best exemplifies Tesla's imaginative thinking, as it represents his humanistic vision of producing and transmitting free energy even to the most distant and inaccessible places on the planet.

\subsection{Tesla's Persistence and Perseverance}

Even though persistence, that is, the ability to keep on working on an idea despite problems and other obstacles, is not explicitly mentioned as a characteristic of good leaders by the literature [23], there have been some studies that point out persistence as a crucial characteristic of effective leadership [28,29,31]. For it is indeed persistence and perseverance that makes one pursue and achieve one's goals and thus realize one's vision. Nikola Tesla is a case in point.

The first incident in Tesla's life that demonstrated his persistence, perhaps coupled with his passion for the study of electricity, which he had developed while in high school, is when he fell ill after he had contracted a form of cholera. Tesla, while bedridden for about a year and with slim chances to survive death, said to his father that he would perhaps recover from his illness if his father let him become an electrical engineer. This is important to mention given that his father had intended young Nikola to become a clergyman. The second major incident is when Tesla began his college education at the Graz Polytechnic Institute, in Austria. It was Tesla's persistence and perseverance that made him not lose hope and pursue his idea of AC electricity. This is also important to mention given that Tesla's mere mention of AC in the lecture rooms, not only brought scorn but also enraged his professors.

Tesla's nervous breakdown, due to the stress that he had experienced while working at the government telegraph office in Budapest, is another incident that illustrates his persistence and willpower to live and continue to work. It was there in Budapest and during his walks in the Budapest Park (as part of his recovery process) that he finally solved the problem of AC. The hypersensitivity that he developed due to the nervous breakdown did not deter Tesla from pursuing his dream to go to the United States of America and work on the idea of AC electricity.

It was while in the United States that he demonstrated his extraordinary abilities to persist and persevere, despite the obstacles and the difficulties that he encountered. Tesla, after he worked at the Continental Edison Company in Paris, and having realized that Europe was not very interested in his idea of AC, decided (under the advice of Continental Edison's chairman) to travel to the United States and work for Thomas Edison. His adolescence dream, as Tesla used to say, to harness the power of Niagara Falls, may after all be realized. Upon his arrival there, Tesla immediately began working for Thomas Edison, who was really impressed at Tesla's skill as a trouble-shooter, and also at his incredible work-rate. However, Tesla, after he was infuriated by Edison, who did not keep his promise to pay him what he had promised, quit and left. This was the beginning of a controversy between the two men that took the form of a battle, known as the "War of Currents" (i.e., in an attempt to demonstrate the dangers of AC power, Edison sponsored an electrical engineer to travel the country electrocuting animals with both DC and AC). However, Edison was bent not only on showing the bad effects of AC but also on smearing Tesla's name. The result was that Tesla began to dig ditches for about two years, for a dollar a day, in order to survive.

It must have been his passion for and his perseverance in pursuing his work on $\mathrm{AC}$ electricity, perhaps his faith in the ultimate victory of $\mathrm{AC}$, that did not discourage Tesla. It is a fact that Westinghouse, who owned the Westinghouse electric company, heard about Tesla and invited him to his laboratory in Pittsburgh. Having already the experience 
with building dynamos and motors, Tesla began working on generators, and the success came when Tesla materialized his adolescent dream to harness the power of Niagara Falls and sent electrical energy at a distance of $25 \mathrm{~km}$ away, something unheard of at the time. This was the best justification of the superiority of AC electricity. However, immediately after that success, a fire completely destroyed his New York laboratory. However, his extraordinary persistence and perseverance were displayed once again; Tela was not discouraged at all. On the contrary, he made the decision to go west, after he secured funding, and set up a laboratory at Colorado Springs.

\subsection{Tesla's Vision}

Vision, according to the literature on leadership [20-22], is considered a central trait of effective leadership, because without it there is neither direction nor inspiration. Tesla was a visionary. His vision was to send free electrical energy to all people on the planet. Thus, he began to work on the idea of the wireless transmission of electrical energy. Even though that was an impossible idea, as scientists would say, Tesla put all his energy to materialize it. Given that the notions of leadership and vision are both about change, or rather about one's ability to see the potential for change, Tesla was indeed a leader in his field, or what Howard Gardner calls a 'leading mind" [21]. Having been aware that DC electricity was inefficient and incapable of transmitting power over long distances (due to the progressive loss of power), Tesla saw the potential of AC electricity to change the world.

What deserves to be noted, though, is that Tesla's vision to send free electrical power to all places, even the most distant ones on the planet, encapsulated human values which cannot and should not be simply associated with his work and his innovative experiments. For it was his humanistic vision that sustained his work, despite a 'war' that was waged against him by Thomas Edison and the American establishment, as well as the hardships that had worn him out. Even though Tesla's humanitarian vision was not realized-even today sending free energy to the whole world today may very well sound unrealistic due to a variety of reasons (e.g., political, financial), his vision, as an idea, still inspires scientists and electrical engineers alike. Moreover, the questions and the issues raised by such a possibility can provide food for thought for those who are still inspired by his vision [24].

\section{The Significance of the Nikola Tesla Story}

There is no doubt that Tesla's personal/leadership traits represent human qualities that young students, both male and female, can associate with in order to cope with and succeed in the 'real world'. If some people (e.g., singers, athletes, scientists) become 'heroes' or 'heroines' for the young students, those 'heroes' or 'heroines' are chosen because they embody human qualities and values. Therefore, if a story is to be used as a teaching tool, it is crucial that it includes in its plot life events from which emerge the personal traits of scientists. Such life events do not only provide a context for teaching curriculum content, but also, as was pointed out, can make the story more engaging. Such an engaging story has the potential to influence students, especially if we consider that human beings are indeed "storytelling animals" [59].

The influence that Nikola Tesla as an extraordinary mind [24,27] can have on young students is something that should be seriously considered, if students are also to be helped to find their own extraordinariness. For it is important to recognize the hidden potential for 'extraordinariness' in many individuals, who, for one reason or another, remain obscure. Howard Gardner's line of investigation points to the probability that "for every William Butler Yeats or Marie Curie who makes his or her way into encyclopedias, there are individuals of equal potential" (p. 5) [60]. From such a perspective, it makes sense to use stories that present the work and the life events of extraordinary scientists, who can play the role of influencers. It is true that, throughout history, there has been a love-hate relationship with extraordinary individuals and sometimes a reluctance to recognize their achievements. Even after these achievements have been acknowledged, very often, there is a search for signs of weakness and reasons to denigrate those individuals [60]. However, 
there seems to be no question that Nikola Tesla was a genius. (He held over 700 registered patents, and the US Supreme Court, right after his death, held Marconi's patent for the radio invalid and recognized Tesla's contribution to the invention of the radio technology.) Most important of all, Tesla was an individual whose work helped divert the course of human history and thus change our world.

While extraordinariness, as Gardner's analysis shows, does not necessarily or always translate into working for the social good [60], Tesla's work was inspired by a humanitarian vision: Electricity for all people on Earth. It is for this reason that Tesla should be considered an influencer in the context of education. One should be reminded that an education, if it is to attract students to STEM fields, ought to foster an understanding of scientific ideas (i.e., science content) and their importance [61-63]. The Nikola Tesla story, based on his life-events, wonderfully integrates science content knowledge and its importance into the plot. It is precisely this integration that has the potential to make science accessible even to young students. What Nobel Laureate Richard Feynman argued [64] can provide educators and curriculum designers with some food for thought:

Hardly anyone can understand the importance of an idea, it is so remarkable. Except that, possibly, some children catch on. And when a child catches onto an idea [ ... ] we have a scientist. These ideas do filter down [ ... ] and lots of kids get the spirit-and when they have the spirit you have a scientist. It's too late for them to get the spirit when they are in our universities, so we must attempt to explain these ideas to children.

(p. 6)

Funding: This study received no external funding.

Institutional Review Board Statement: Not applicable.

Informed Consent Statement: Not applicable.

Data Availability Statement: Not applicable.

Conflicts of Interest: The author declares no conflict of interest.

\section{References}

1. Avraamidou, L.; Osborne, J. The role of narrative in communicating science. Int. J. Sci. Educ. 2009, 31, 1017-1683. [CrossRef]

2. Dahlstrom, M. Using narratives and storytelling to communicate science with nonexpert audiences. Proc. Natl. Acad. Sci. USA 2014, 111 (Suppl. 4), 13614-13620. [CrossRef] [PubMed]

3. Kokkotas, P.; Rizaki, A.; Malamitsa, K. Storytelling as a strategy for understanding concepts of electricity and electromagnetism. Interchange 2010, 41, 379-405. [CrossRef]

4. Klassen, S. A theoretical framework for contextual science teaching. Interchange 2006, 37, 31-61. [CrossRef]

5. Klassen, S. The construction and analysis of a science story. Sci. Educ. 2009, 18, 401-423. [CrossRef]

6. Corni, F.; Gilberti, E.; Mariani, C. A Story as Innovative Medium for Science Education in Primary School. 2010. Available online: https:/ / personale.unimore.it/rubrica/pubblicazioni/corni (accessed on 12 March 2015).

7. Kreps-Frisch, J. The stories they'd tell: Pre-service elementary teachers writing stories to demonstrate physical science concepts. J. Sci. Teach. Educ. 2010, 21, 703-722. [CrossRef]

8. Bruner, J. Actual Minds, Possible Worlds; Harvard University Press: Cambridge, MA, USA, 1986.

9. Hadzigeorgiou, Y. Narrative thinking and storytelling in science education. In Imaginative Science Education. The Central Role of Imagination in Science Education; Springer: Berlin/Heidelberg, Germany, 2016. [CrossRef]

10. Bruner, J. The Culture of Education; Harvard University Press: Cambridge, MA, USA, 1996.

11. Martin, B.; Brouwer, W. Exploring personal science. Sci. Educ. 1993, 77, 441-459. [CrossRef]

12. Heering, P. False friends: What makes a story inadequate for science teaching? Interchange 2010, 41, $323-333$.

13. Egan, K. An Imaginative Approach to Teaching; Jossey-Bass: San Francisco, CA, USA, 2005.

14. Egan, K.; Stout, M.; Takaya, K. Teaching and Learning Outside the Box: Inspiring Imagination Across the Curriculum; Alhouse Press: London, ON, Canada, 2007.

15. Hadzigeorgiou, Y. Humanizing the teaching of physics through storytelling: The case of current electricity. Phys. Educ. 2006, 41, 42-46. [CrossRef]

16. Hadzigeorgiou, Y.; Garganourakis, V. Using Nikola Tesla's story and experiments, as presented in the film "The Prestige", to promote scientific inquiry. Interchange 2010, 41, 363-378. [CrossRef] 
17. Hadzigeorgiou, Y.; Klassen, S.; Froese-Klassen, C. Encouraging a 'romantic understanding' of science: The effect of the Nikola Tesla story. Sci. Educ. 2012, 21, 1111-1138. [CrossRef]

18. Hadzigeorgiou, Y.; Schulz, R. What really makes secondary school students "want" to study physics? Educ. Sci. 2017, 7, 84. [CrossRef]

19. Hong, H.-Y.; Lin-Siegler, X. How learning about scientists' struggles influences students' interest and learning in physics. J. Educ. Psychol. 2012, 104, 469-484. [CrossRef]

20. Bennis, W. On Becoming a Leader; Basic Books: New York, NY, USA, 2009.

21. Gardner, H. Leading Minds: An Anatomy of Leadership; Basic Books: New York, NY, USA, 1995.

22. Gibbins-Klein, M. The Thoughtful Leader: How to Use Your Head and Your Heart to Inspire Others; Panoma Press Ltd.: London, UK, 2015.

23. Caldwell, C. Moral Leadership: A transformative Model for Tomorrow's Leaders; Business Expert Press: New York, NY, USA, 2012.

24. Carlson, B. Tesla: Inventor of the Electrical Age; Princeton University Press: Princeton, NJ, USA, 2013.

25. Cheney, M.; Uth, R. Tesla: Master of Lightning; Barnes and Noble: New York, NY, USA, 1999.

26. Jonnes, J. Empires of Light: Edison, Tesla, Westinghouse, and the Race to Electrify the World; Random House: New York, NY, USA, 2003. Lomas, R. The Man Who Invented the Twentieth Century: Nikola Tesla, Forgotten Genius of Electricity; Headline: London, UK, 2000. Chai, M. Personality and Leadership Qualities Among Student Leaders. Am. J. Appl. Psychol. 2015, 4, 27-32. [CrossRef]

29. Fernald, L.; Solomon, G.; Tarabishy, A. A New Paradigm: Entrepreneurial Leadership. South. Bus. Rev. 2005, 30, 1-10.

30. Gini, A.; Green, R.M. 10 Virtues of Outstanding Leaders: Leadership and Character; John Wiley \& Sons: Chichester, UK, 2013.

31. Kirkpatrick, S.; Locke, E. Do leadership traits matter? Acad. Manag. Perspect. 1991, 5, 48-60. [CrossRef]

32. Johnston, B. (Ed.) My Inventions: The Autobiography of Nikola Tesla; Hart Brothers: Williston, VT, USA, 1983.

33. O'Neil, J. Prodigal Genius: The Llife of Nikola Tesla; Tesla Book Company: Chula Vista, CA, USA, 1992.

34. Seifer, M. Wizard: The Life and Times of Nikola Tesla; Citadel Press: New York, NY, USA, 1998.

35. Tesla Society. Tesla Memorial Society of New York. Available online: http:/ / www.teslasociety.com (accessed on 18 July 2021$)$.

36. Tesla, N. My Inventions; Ben Johnson: New York, NY, USA, 1982.

37. Cheney, M. Tesla: Man Out of Time; Prentice-Hall: Englewood Cliffs, NJ, USA, 1981.

38. Egan, K. Teaching as Storytelling; University of Chicago Press: Chicago, IL, USA, 1986.

39. Zak, P. Trust Factor: The Science of Creating High-Performance Companies; Brilliance Audio: Grand Haven, MI, USA, 2017.

40. Aidman, B.; Long, T.A. Leadership and storytelling. Promoting a culture of learning, positive change, and community. Leadersh Res. Educ 2017, 4, 106-126.

41. Judson, G. What's the Story on Imagination in Educational Leadership? 2020. Available online: http: / /www.educationthatinspires. $\mathrm{ca} / 2020 / 01 / 23$ / whats-the-story-on-imagination-in-educational-leadership / (accessed on 17 July 2021).

42. Hadzigeorgiou, Y.; Stivaktakis, S. Encouraging involvement with school science. J. Curric. Pedagog. 2008, 5, 138-162. [CrossRef]

43. AAAS. Science for all Americans. Scientific Literacy; Oxford University Press: New York, NY, USA; Oxford, UK, 1990.

44. NRC. Taking Science to School: Learning and Teaching Science in Grades K-8; The National Academy Press: Washington, DC, USA, 2007.

45. Williams, C.; Stanisstreet, M.; Spall, K.; Boyes, E.; Dickson, D. Why aren't secondary school pupils interested in physics? Phys. Educ. 2003, 38, 324-329. [CrossRef]

46. Jenkins, E. Student opinion in England about science and technology. Res. Sci. Technol. Educ. 2006, 24, 59-68. [CrossRef]

47. Jenkins, E.; Pell, R. The Relevance of Science Education Project (ROSE) in England: A Summary of Findings; Centre for Studies in Science and Mathematics Education, University of Leeds: Leeds, UK, 2006.

48. Jenkins, E.; Nelson, N. Important but not for me: Students' attitudes toward secondary school science in England. Res. Sci. Technol. Educ. 2005, 23, 41-57. [CrossRef]

49. Ceci, S.; Ginther, D.; Kahn, S.; Williams, W. Women in academic science: A changing landscape. Psychol. Sci. 2014, 15, 75-141. [CrossRef]

50. Wang, M.; Eccles, J.; Kenny, S. Not lack of abilities but lack of choice: Individual and gender differences in choice of careers in science, technology, engineering, and mathematics. Psychol. Sci. 2013, 14, 1-6. [CrossRef] [PubMed]

51. Egan, K. Primary Understanding; The University of Chicago Press: Chicago, IL, USA, 1988.

52. Kubli, F. Can the theory of narratives help science teachers be better storytellers? Sci. Educ. 2001, 10, 595-599. [CrossRef]

53. Egan, K. The Educated Mind: How Cognitive Tools Shape Our Understanding; University of Chicago Press: Chicago, IL, USA, 1997.

54. Roberts, B. Biographical Research; Open University Press: London, UK, 2002.

55. Rollyson, C. Biography: A User's Guide; Ivan, R. Dee Inc.: Chicago, IL, USA, 2008.

56. Denzin, N. Interpretive Biography; SAGE Publications: Thousand Oaks, CA, USA, 1989.

57. Raptis, N.; Mousenna, H.; Kouroutsidou, M. 'Imaginative Leadership': On the centrality of imagination in effective leadership. Int. J. Educ. Organ. Leadersh. 2021, 28, 83-96. [CrossRef]

58. Goethals, G.; Sorenson, G.; Burns, G.M. (Eds.) Encyclopedia of Leadership; Sage: Thousand Oaks, CA, USA, 2004.

59. Gottschall, J. The Storytelling Animal: How Stories Make Us Human; Houghton Mifflin Harcourt: Boston, MA, USA; New York, NY, USA, 2012.

60. Gardner, H. Extraordinary Minds: Portraits of 4 Exceptional Individuals and an Examination of Our Own Extraordinariness; Basic Books: New York, NY, USA, 1997. 
61. Hadzigeorgiou, Y. A critique of science education as sociopolitical action from the perspective of liberal education. Sci. Educ. 2015, 24, 259-280. [CrossRef]

62. Hadzigeorgiou, Y. Inclusive Practice in Science Education: Fulbright Project_Part I: Theoretical Framework; Department of Curriculum \& Instruction, University of Northern Iowa: Cedar Falls, IA, USA, 2005.

63. Millar, R.; Osborne, J. Beyond 2000. Science Education for the Future. 1998. Available online: http://www.kcl.ac.uk/content/1/ c6/01/32/03/b2000.pdf (accessed on 15 February 2015).

64. Feynman, R. The value of science. In Science and Ideas; Arons, A., Bork, A., Eds.; Prentice Hall: Englewood Cliffs, NJ, USA, 1964; pp. 3-12. 